\title{
Assessment of Ground Water Quality for Drinking Purpose in Algezira Islanj and Huraizab Area, Omdurman, Sudan
}

\author{
Muna I. Shumo \\ University of Bahri
}

Gamereldawla O. E. Isa

University of Bahri

Osama A. Saeed

University of Bahri

Ahmed M. Abdalnabe

University of Bahri, College of Applied and Industrial Sciences, Khartoum, Sudan

Tarig Osman Khider ( $\nabla$ tarigosmankhider@gmail.com )

University of Bahri https://orcid.org/0000-0003-4494-8402

\section{Data Note}

Keywords: Physical properties, chemical constituents, ground water, drinking water, Omdurman

Posted Date: February 1st, 2021

DOI: https://doi.org/10.21203/rs.3.rs-191131/v1

License: (9) This work is licensed under a Creative Commons Attribution 4.0 International License. Read Full License 


\section{Abstract}

Objective This work was carried to study the suitability of ground water taken from Algezira Islanj and Huraizab areas, north Omdurman, Sudan for drinking compared with parameters and standards of World Health Organization. Omdurman is situated at the junction of the Blue and the White Nile.

Results Six samples were taken from the groundwater in north of Omdurman mainly ( Algezira Islanj and Huraizab areas). The samples were subjected to physical and chemical examinations. The main investigated parameters were, total dissolved solid, $\mathrm{pH}$, turbidity, electrical conductivity, alkalinity, total hardness and heavy metals. The turbidity level from Algezira Islanj was in range of (7.10 - 21.40) which was higher than the acceptable level for drinking water stated by World Health Organization (WHO), and Sudanese Standards and Metrology Organization (SSMO) specifications. The levels of alkalinity, total dissolved solids and hardness in all samples were in the range. Ammonia content from Huraizab samples were higher than the maximum value $(1.5 \mathrm{mg} / \mathrm{L})$. The study showed that the concentrations of iron, arsenic, nickel, and lead for groundwater in the study area were higher than the permitted limits suggested by World Health Organization and Sudanese Standards and Metrology Organization specifications.

\section{Introduction}

Water is vital natural resources for living organisms and human being. It effects the life and economy of surrounding people of certain area [1]. The world health organization [2] mentioned that a number of organic and inorganic chemicals have been reported in drinking water, with ow or high concentrations, the chemicals indicated include the potential hazards to mankind. One billion of people in the world do not has access to safe water and 2.5 billion lack access to adequate sanitation services [3]. Ground water comes from small percentage of precipitation that falls, in filtrates, traveling downward, and fills the available pore spaces within rock sand, gravel, and clay. This forms a large subsurface storage area of water which interacts with various rocks, minerals, microorganisms, most chemicals contact the ground water can be positive or negative to water quality [4]. Contaminants such as, heavy metals, nitrates, salt, bacteria and viruses reaches water supplies due to inadequate treatment and disposal of waste (human and livestock), industrial discharges, and over-use of limited water resources [5]. High levels of metals and other chemicals that can harm people health. Chemicals containing arsenic, barium, chromium mercury, nickel, , lead, selenium , copper and zinc, effect natively on human health (Kidney, liver and brain) [6]. Sudan is one of the largest country in Africa and lies mostly in the arid region where water limited resource, however it is considered to be rich in water resources. The available water resources are Nile system, rain water and ground water [7]. The objective of this study was to investigate the physical and chemical parameters of six water samples collected from ground water from Algezira Islanj and Huraizab water stations resources and compare the results values with the Global standards (world health organization) and local standards (Sudanese Standards and Metrology Organization).

\section{Main Text}


Al gezira Islanj and Huraizab are villages are located about $10 \mathrm{~km}$ northeast of Omdurman city and are a part of Karary locality that lies between longitudes 15 -11.5/16- 39.5 east and latitudes in 32-36.5 / 31 -37 north. The population is about 12 thousand people for both regions. The distance from Algezira Islanj to Huraizab is about $5.4 \mathrm{~km}$. Algezira Islanj contains 4 main wells, while Al Huraizab contains two main wells for drinking water supply as showed in Figure 1

Ground water samples were taken from Algezira Islanj in from four stations (A, B, C and D) and Huraizab two stations ( $E$ and $F$ ), the depth between 13-20 m. Water samples were taken after allowing the water pumps, from wells, to run for short time to remove the first water flushes, one and a half liters were collected in clean plastic bottles and half liter were collected in clean glass bottles. The bottles were rinsed twice with water before collection, and the samples are acidified with $1.5 \mathrm{ml}$ of nitric acid per liter, closed and immediately transported to laboratory for physical and chemical analysis. These samples are stored at $4^{\circ} \mathrm{C}$ before analysis. The samples were collected during the month of July 2020 .

The $\mathrm{pH}$, Electrical conductivity, and total dissolved solid were measured in the field. The $\mathrm{pH}$ was measured using (portable-jenway $\mathrm{pH}$ meter). Electrical conductivity and total dissolved solid were measured using HQ30d-HACH conductivity meter. Turbidity was measured using TL2360-HACH Turbidity meter. Total hardness of water expressed as calcium carbonate, measured by Ethylene diamine tetra acetic acid EDTA titrimetric method. Alkalinity, calcium content and chloride were determined by titration method. Magnesium was determined by subtracting the calcium hardness from total hardness as $\mathrm{mg} / \mathrm{L}$. Sodium and potassium were determined by using Flame photometric method (Flame photometer). Nitrate, ammonia, Phosphate and Silica were determined by using spectrophotometer DR HACH (5000). Iron, Zinc, Lead, Arsenic and Nickel were determined by using inductively coupled plasma mass spectrometry (ICP-MS).

Table 1 showed pH values, electrical conductivity (EC), total dissolved solid (TDS) and turbidity levels.

Table 1. pH, electrical conductivity (EC), total dissolved solid (TDS) and turbidity levels for six water samples collected from Al gezira Islanj and Huraizab areas, Omdurman Sudan.

\begin{tabular}{|lllllll|}
\hline Parameter & A & B & C & D & E & F \\
\hline pH & 7.20 & 7.10 & 7.00 & 7.10 & 7.10 & 7.10 \\
EC & 813 & 402 & 853 & 451 & 868 & 595 \\
\hline TDS & 534 & 226 & 503 & 247 & 508 & 319 \\
\hline Turbidity & 13.40 & 7.10 & 21.40 & 9.20 & 1.84 & 1.02 \\
\hline
\end{tabular}

The levels of alkalinity (Table 1 supplementary materials), total dissolved solids and hardness in all 
samples were in the range. All the $\mathrm{pH}$ values, electrical conductivity (EC), total dissolved solid (TDS) fall within the acceptable level of WHO (1993) and SSMO (2002) standards (6.5-8.5).

The readings of turbidity in ground water from Algezira Islanj stations $(A, B, C$ and $D)$ fall above the maximum level of WHO (1993) and SSMO (2002) standards ( $\geq 5$ NTU), while the readings of turbidity in ground water from Huraizab water stations $(E$ and $F$ ) fall in the range. The highest value of turbidity (21.40NTU) was found in (A) sample, while the lowest value (1.02NTU) was found in (F) sample. High turbidity of water is often associated with high levels of disease causing organisms such as viruses, parasites and bacteria responsible for symptoms such as nausea, cramps and diarrhea [8].

The total hardness and alkalinity readings fall below the maximum level of WHO (1993) and SSMO (2002) standards for maximum level (500mg/L)

The highest values of concentrations of chloride, ammonia, phosphate, silica and nitrate in $(\mathrm{mg} / \mathrm{L})$ were found in station (E), (F), (D), (F), and (A) respectively (Figure 1 supplementary materials). Except ammonia all these readings fall below the maximum level of WHO (1993) and SSMO (2002) standards for maximum level $(500 \mathrm{mg} / \mathrm{L})$. Ammonia content from Huraizab samples were higher than the maximum value $(1.5 \mathrm{mg} / \mathrm{L})$. Presence of ammonia in ground water may be attributed to natural minerals or through pollution by application of fertilizer, sewage and industrial waste [9].

Table 2. Iron, zinc, lead, arsenic and nickel values present in six water samples collected from Al gezira Islanj and Huraizab areas, Omdurman Sudan

\begin{tabular}{|lllllll|}
\hline Parameter & $\mathrm{A}$ & $\mathrm{B}$ & $\mathrm{C}$ & $\mathrm{D}$ & $\mathrm{E}$ & $\mathrm{F}$ \\
Iron & 0.837 & 1.352 & 0.753 & 0.947 & 0.656 & 0.616 \\
Zinc & 1.670 & 2.340 & 3.020 & 0.120 & 1.350 & 1.270 \\
Lead & 0.278 & 0.270 & 0.275 & 0.274 & 0.279 & 0.271 \\
Arsenic & 0.286 & 0.260 & 0.278 & 0.293 & 0.277 & 0.301 \\
Nickel & 0.117 & 0.122 & 0.123 & 0.119 & 0.125 & 0.116 \\
\hline
\end{tabular}

From (Table 2) the highest values for iron, zinc, lead, arsenic, and nickel were found in station (B), (C), (E), $(F)$ and $(C)$ respectively. Except zinc, all these readings of trace elements fall above the maximum acceptable level, of WHO (1993) and SSMO (2002) standards. Lead concentration scale in all studied samples are exceeding compared WHO Standards, all water samples were shown Lead contain in levels above the maximum contaminant Level $(0.01 \mathrm{mg} / \mathrm{L})$ with the maximum concentration detected being $(0.279 \mathrm{mg} / \mathrm{L})$, these results are of concern as lead has been recognized for centuries as a cumulative general metabolic poison [10]. High values may be due to the effects of discharge of industrial effluents compounds including heavy metals [11]. As well as with reduced intelligence quotient in children and 
with attention disorders Lead enters into environment from industry, mining, plumbing, gasoline, coal, and as a water additive [12]. The elevated levels of arsenic in the study area may be due to its evaporative environment since the climate of this region is arid which can lead to more loss of water by evaporation than its gain by rainfall. Arsenic contamination is also strongly associated with high concentrations of iron, phosphate, and ammonium ions, and anthropogenic activities such as excessive groundwater withdrawal for agricultural irrigation [13]. The major source of metal pollution in water is use of pesticides in the form of calcium arsenate, lead arsenate, sodium arsenate and arsenic acid (Figure 2 supplementary materials) [14]. Iron is the second most abundant metal in the earth's crust. it may be released to water from natural deposits, industrial wastes, refining of Iron ores, and corrosion of Iron containing metals. The maximum allowable limit for Iron as per WHO guidelines is (0.3 $-0.947 \mathrm{mg} / \mathrm{L})$, Iron concentration levels in all studied samples are exceeding then compared WHO Standards. Nickel concentrations in groundwater depend on the soil use, $\mathrm{pH}$, and depth of sampling, the primary source of nickel in drinking-water is leaching from metals in contact with drinking-water, such as pipes and fittings. However, nickel may also be present in some groundwater as a consequence of dissolution from nickel ore-bearing rocks. Acid rain increases the mobility of nickel in the soil and thus might increase nickel concentrations in groundwater [15].

\section{Limitations}

This work concluded that groundwater in the study area is chemically unsuitable for drinking use. The analysis of water samples revealed that the groundwater samples from almost all the locations is highly contaminated with some heavy metals, turbidity and ammonia. It is recommended to carry out a continuous water quality monitoring program and development of effective management practices for utilization of water resources. However due to lack of some lab facilities and more sophisticated and advanced equipment, as well as lack of funding.

\section{Declarations}

\section{Acknowledgments}

The authors would like to express their thanks to College of Applied and Industrial Sciences University of Bahri for using their facilities and support, with all data and materials are available,

\section{Authors' contributions}

MIS and GOE were designed and supervised the work OAS and AMA carried out practical and technical work and revised the draft manuscript. TOK rewrite the article and review the draft manuscript, OAS and AMA were collected the samples draft manuscript .All authors read and approved the final manuscript.

\section{Competing interests}


Not applicable.

\section{Availability of data and materials}

We have already included most of data in the manuscript, the lab and data, some data not included in the manuscript attached as Additional file.

\section{Consent for publication}

Not applicable.

\section{Ethics approval and consent to participate}

Not applicable.

\section{Funding}

Not applicable.

\section{References}

[1] Brandt, Malcolm, J. War, T. and Alan, C. Fresh Water resources and the Rehabilitation of degraded area in the dry lands. Water supply $5^{\text {th }}$ Ed Chad and Djamena-N. Series No.1. 2000.

[2] World Health Organization Guide Lines for Drinking Water Quality, Geneva. 1993.

[3] TWAS. Safe drinking water-the need, the problem, solutions and an action plan, Third world academy of sciences, Trieste, Italy. 2002.

[4] Twort A.C., Law F.M. and Crowley F. W. Water Supply third edition. 1985

[5] Allen, E.H. and K.H. Nancy. Design of measurement systems for water analysis in Lenard .L.C. (ed) ,water and water pollution handbook, 1972, p( 179 - 197).

[6] Fletcher G. Drisocll .Ground water and wells. Second edition Chapter six, . 1989 p 90-120.

[7] Ammar M.S, Nabil H.H, Bashir, Azhari O.A and Yousif O.HHeavy Metals Concentrations in Drinking Water in Dongola and Merowe, Northern State, Sudan". EC Pharmacology and Toxicology. 2018. 6. (9):829-837.

[8] Memon A. H., Ghanghro A.B., Jahangir TM, Lund GM. Arsenic contamination in drinking water of District Jamshoro, Sindh, Pakistan. Biomed Lett 2016 2(1):31-37.

[9] Alemu Z. A., Teklu K. T., Alemayehu T. A., Balcha K. H., Mengesha S. DPhysicochemical quality of drinking water sources in Ethiopia and its health impact: a retrospective study. Environ Syst Res. 2015 
[10] Adepoju-Bello, A. A., Ojomolade 0.O., Ayoola G.A. and Coker H. A. B., Quantitative analysis of some toxic metals in domestic water obtained from Lagos metropolis. The Nig. J. Pharm. 2009. 42(1): 57-60.

[11] Yule W. and M. RutterEffect on Children's Behavior and Cognitive Performance: A Critical Review. In: Dietary and Environmental Lead (Pb): Human Health Effects. R. Mahaffey, (Ed.). New York: Elsevier, , 1985. pp: 211-251.

[12]Needleman, H. L., The current status of childhood low-level lead toxicity. Neurotoxicology, 1993,. 14: 161-166.

[13] Kumar P, Kumar M, Ramanathan A, Tsujimura M.Tracing the factors responsible for arsenic enrichment in groundwater of the middle Gangetic Plain, India: a source identification perspective. Environ Geochem Health 2010. 32:129-146.

[14] Rasool A, Xiao T., Farooqi A., Shafeeque M., Liu Y., Kamran M. A., Katsoyiannis I. A., Eqani SAMAS. Quality of tube well water intended for irrigation and human consumption with special emphasis on arsenic contamination at the area of Punjab, Pakistan 2016. doi:10.1007/s10653-016-9855-8.

[15] World Health Organization International Program on Chemical Safety (Environmental Health Criteria 108) IPCS Nickel. Geneva. 1991.

\section{Figures}




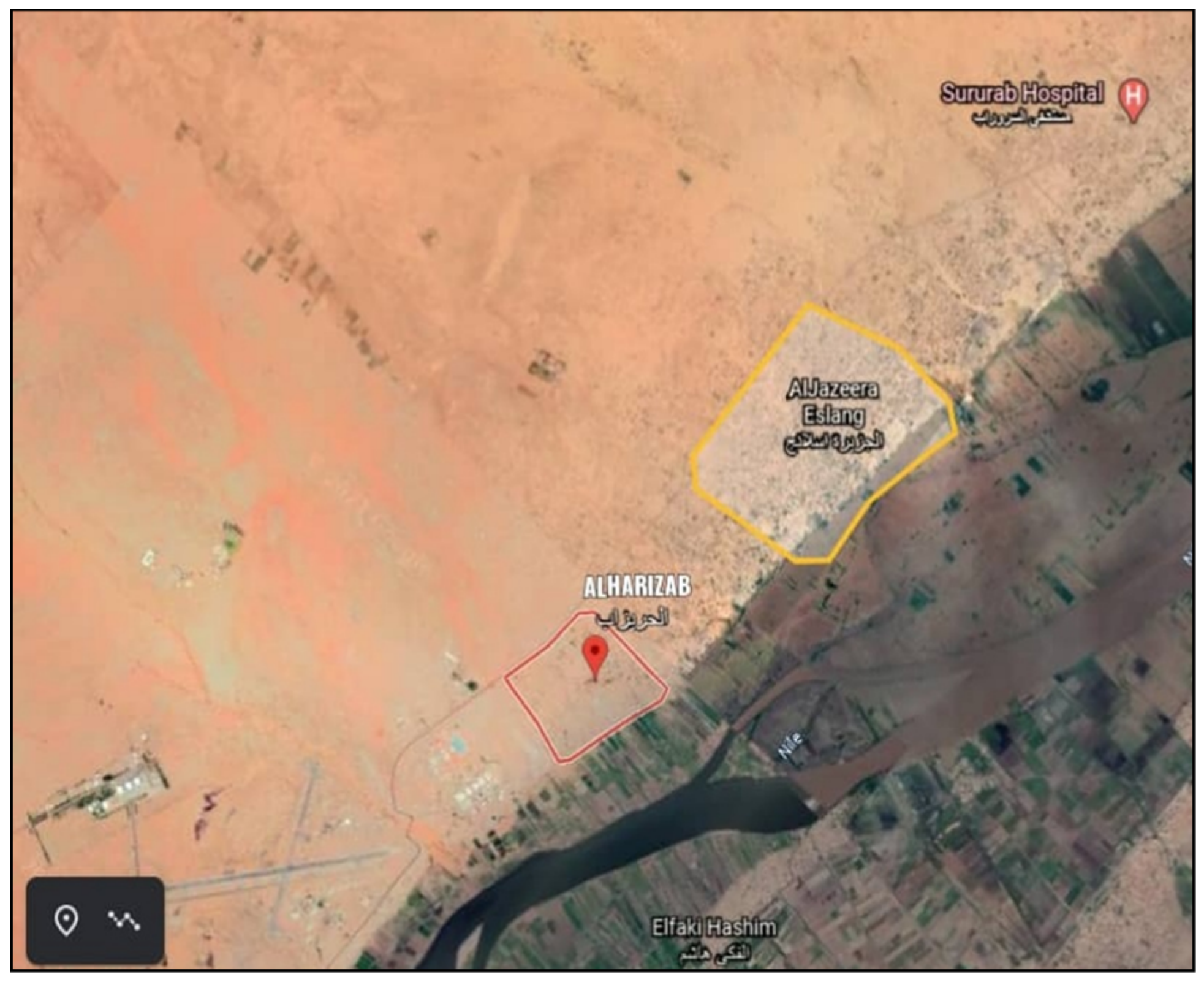

\section{Figure 1}

The map of Algezira Islanj and Huraizab areas, Omdurman, Sudan.

\section{Supplementary Files}

This is a list of supplementary files associated with this preprint. Click to download.

- Supp.materials.doc 